
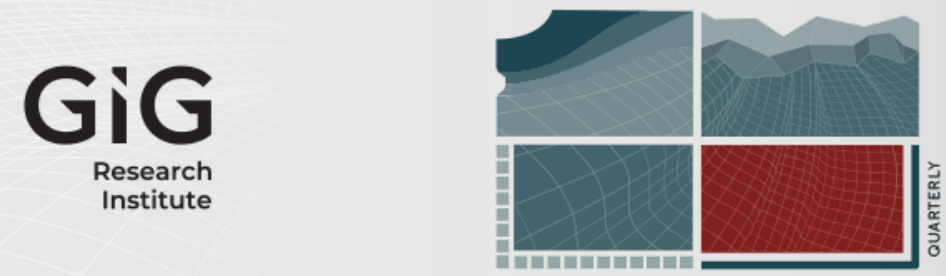

JOURNAL

OF

SUSTAINABLE

MINING

\title{
Evaluation of undeveloped hard coal deposits and estimation of hard coal reserves in the Upper Silesian Coal Basin, Poland
}

Author(s) ORCID Identifier:

Tomasz Urych (iD 0000-0003-1827-028X

Jarosław Chećko (iD) 0000-0001-7926-1702

Marek Rosa (iD) 0000-0002-2927-8837

Anna Wątor (iD) 0000-0003-4243-0853

Follow this and additional works at: https://jsm.gig.eu/journal-of-sustainable-mining

Part of the Geological Engineering Commons, Geology Commons, Mining Engineering Commons, and the Natural Resources Management and Policy Commons

\section{Recommended Citation}

Urych, Tomasz; Chećko, Jarosław; Rosa, Marek; and Wątor, Anna (2020) "Evaluation of undeveloped hard coal deposits and estimation of hard coal reserves in the Upper Silesian Coal Basin, Poland," Journal of Sustainable Mining: Vol. 19 : Iss. 4 , Article 3.

Available at: https://doi.org/10.46873/2300-3960.1026

This Research Article is brought to you for free and open access by Journal of Sustainable Mining. It has been accepted for inclusion in Journal of Sustainable Mining by an authorized editor of Journal of Sustainable Mining. 


\title{
Evaluation of undeveloped hard coal deposits and estimation of hard coal reserves in the Upper Silesian Coal Basin, Poland
}

\begin{abstract}
The article presents the results of works concerning evaluation of undeveloped deposits in the Upper Silesian Coal Basin and an estimation of hard coal reserves which can be developed by 2050 . Evaluation of hard coal deposits was established on criterions choice and their score determination. On the basis of obtained the final score and after consultations with experts in the field of hard coal mining, there were selected three areas of undeveloped deposits with the amount of about $1.99 \mathrm{Gt}$ (billion metric tons) of anticipated economic resources which can extend the coal reserve base located in the direct vicinity of operating hard coal mines. Additionally, one undeveloped coal deposit with estimated resources amounts to about $1.15 \mathrm{Gt}$ was selected as a potential deposit whose resources could be included in the reserves of operating mines, up to the depth of 1,500 metres. Deposit areas were selected and hard coal reserves were estimated with a view to building new coal mines. For Oświęcim-Polanka deposit, there was built a 3D geological model with estimated the amount of $924 \mathrm{Mt}$ (million metric tons) of anticipated economic resources of coal. An example of a deposit development with ventilation, extraction and transport/ haulage underground roadways connecting coal seams with the surface are presented. The designed mine working was placed in the 3D geological deposit model which is a useful tool for designing spatial deposit management.
\end{abstract}

\section{Keywords}

coal resources, coal reserves, 3D geological model, Petrel software, Upper Silesian Coal Basin

\section{Creative Commons License}

(c) (i) $\ominus$

This work is licensed under a Creative Commons Attribution-Noncommercial-No Derivative Works 4.0 License. 


\title{
Evaluation of undeveloped hard coal deposits and estimation of hard coal reserves in the Upper Silesian Coal Basin, Poland
}

\author{
Tomasz Urych*, Jarosław Chećko, Marek Rosa, Anna Wątor \\ Central Mining Institute, Department of Geology and Geophysics, Katowice, Poland
}

\begin{abstract}
The article presents the results of works concerning evaluation of undeveloped deposits in the Upper Silesian Coal Basin and an estimation of hard coal reserves which can be developed by 2050 . Evaluation of hard coal deposits was established on criterions choice and their score determination. On the basis of obtained the final score and after consultations with experts in the field of hard coal mining, there were selected three areas of undeveloped deposits with the amount of about $1.99 \mathrm{Gt}$ (billion metric tons) of anticipated economic resources which can extend the coal reserve base located in the direct vicinity of operating hard coal mines. Additionally, one undeveloped coal deposit with estimated resources amounts to about $1.15 \mathrm{Gt}$ was selected as a potential deposit whose resources could be included in the reserves of operating mines, up to the depth of 1,500 metres. Deposit areas were selected and hard coal reserves were estimated with a view to building new coal mines. For Oświęcim-Polanka deposit, there was built a 3D geological model with estimated the amount of $924 \mathrm{Mt}$ (million metric tons) of anticipated economic resources of coal. An example of a deposit development with ventilation, extraction and transport/haulage underground roadways connecting coal seams with the surface are presented. The designed mine working was placed in the $3 \mathrm{D}$ geological deposit model which is a useful tool for designing spatial deposit management.
\end{abstract}

Keywords: coal resources, coal reserves, 3D geological model, petrel software, Upper Silesian Coal Basin

\section{Introduction}

$\mathrm{M}$ ineral resources are one of basic natural resources, which have direct influence on the economic growth of a country and, in turn, on the standard of life of people living there. That is why information on deposit exploration and its development, documented reserves and the volume of production, is such an important issue. It is estimated that, around the world, there is available over 1 trillion metric tons $\left(1 \times 10^{12}\right)$ of marketable coal reserves, whose exploitation may be economically feasible. It means that, at the present production rate, the reserves of coal will last approximately 150 years. In comparison, the world reserves of oil and gas will last respectively about 50 and 52 years, at the present production rate [1].

After many years of works aimed at searching for and surveying mineral deposits around the world, locations, volume and characteristics of most coal deposits are quite well known. The world coal reserves, as of 2018 , are estimated to be 1,055 billion metric tons $\left(1.055 \times 10^{12}\right)$. The countries with the largest coal reserves are: the USA $(24 \%)$, Russia $(15 \%)$, Australia (14\%) and China (13\%) [2]. Details of coal reserves in given countries are presented in Table 1 and in Fig. 1.

In Poland there is applied a classification of solid mineral resources based on the reporting system developed in 1941 in the USSR and implemented in the middle of the 20th century in Poland as a legal norm in the form of the Geological and Mining Law [3]. According to the classification, resources are

Received 2 October 2020; revised 27 November 2020; accepted 6 December 2020

Available online 15 December 2020

* Corresponding author.

E-mail address: turych@gig.eu (T. Urych). 
Table 1. Total proved reserves of coal, as of the end of 2018 [2].

\begin{tabular}{|c|c|c|c|}
\hline Million tonnes & $\begin{array}{l}\text { Anthracite } \\
\text { and } \\
\text { bituminous }\end{array}$ & $\begin{array}{l}\text { Sub-bituminous } \\
\text { and lignite }\end{array}$ & Total \\
\hline Canada & 4346 & 2236 & 6582 \\
\hline Mexico & 1160 & 51 & 1211 \\
\hline US & 220167 & 30052 & 250219 \\
\hline Total North America & 225673 & 32339 & 258012 \\
\hline Brazil & 1547 & 5049 & 6596 \\
\hline Colombia & 4881 & - & 4881 \\
\hline Venezuela & 731 & - & 731 \\
\hline Other S. \& Cent. America & 1784 & 24 & 1808 \\
\hline Total S. \& Cent. America & 8943 & 5073 & 14016 \\
\hline Bulgaria & 192 & 2174 & 2366 \\
\hline Czech Republic & 110 & 2547 & 2657 \\
\hline Germany & 3 & 36100 & 36103 \\
\hline Greece & - & 2876 & 2876 \\
\hline Hungary & 276 & 2633 & 2909 \\
\hline Poland & 20542 & 5937 & 26479 \\
\hline Romania & 11 & 280 & 291 \\
\hline Serbia & 402 & 7112 & 7514 \\
\hline Spain & 868 & 319 & 1187 \\
\hline Turkey & 551 & 10975 & 11526 \\
\hline Ukraine & 32039 & 2336 & 34375 \\
\hline United Kingdom & 29 & - & 29 \\
\hline Other Europe & 1109 & 5172 & 6281 \\
\hline Total Europe & 56132 & 78461 & 134593 \\
\hline Kazakhstan & 25605 & - & 25605 \\
\hline Russian Federation & 69634 & 90730 & 160364 \\
\hline Uzbekistan & 1375 & - & 1375 \\
\hline Other CIS & 1509 & - & 1509 \\
\hline Total CIS & 98123 & 90730 & 188853 \\
\hline South Africa & 9893 & - & 9893 \\
\hline Zimbabwe & 502 & - & 502 \\
\hline Other Africa & 2756 & 66 & 2822 \\
\hline Middle East & 1203 & - & 1203 \\
\hline Total Middle East \& Africa & 14354 & 66 & 14420 \\
\hline Australia & 70927 & 76508 & 147435 \\
\hline China & 130851 & 7968 & 138819 \\
\hline India & 96468 & 4895 & 101363 \\
\hline Indonesia & 26122 & 10878 & 37000 \\
\hline Japan & 340 & 10 & 350 \\
\hline Mongolia & 1170 & 1350 & 2520 \\
\hline New Zealand & 825 & 6750 & 7575 \\
\hline Pakistan & 207 & 2857 & 3064 \\
\hline South Korea & 326 & - & 326 \\
\hline Thailand & - & 1063 & 1063 \\
\hline Vietnam & 3116 & 244 & 3360 \\
\hline Other Asia Pacific & 1326 & 687 & 2013 \\
\hline Total Asia Pacific & 331678 & 113210 & 444888 \\
\hline Total World & 734903 & 319879 & 1054782 \\
\hline of which: OECD & 322234 & 177484 & 499718 \\
\hline Non-OECD & 412669 & 142395 & 555064 \\
\hline European Union & 22612 & 53356 & 75968 \\
\hline
\end{tabular}

divided, according to the degree of their exploration, into categories D, C2, C1, B and A. Resources in Poland are classified as anticipated economic resources and sub-economic resources, economic resources, non-marketable resources, reserves and

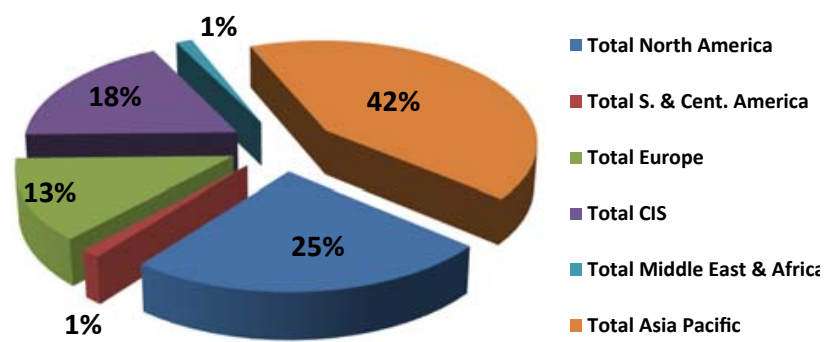

Fig. 1. Distribution of the world's proved reserves of coal in 2018 (based on data from Table 1 [2]).

losses. The Geological and Mining Law contains guidelines for mineral deposits resources/reserves estimation and reporting, including hard coal, based on the cut off criteria and level of confidence. Essentially, it is an inventory of coal, which is recorded by state authorities, while entrepreneurs (mines), basing on their own criteria of economic feasibility, indicate reserves for future production. The criteria take into consideration geological and mining conditions, economic situation, surface protection aspects etc. In spite of the fact that the Polish classification is different from the ones applied abroad, according to experts, it can be compared with them [4-6].

In international classifications, in particular the JORC (Joint Ore Reserves Committee) Code System [7] which is a recognised international system of reporting minerals as resources and reserves, the emphasis is put on the manner of presenting data on resources/reserves and the degree of their formal and economic accessibility for exploitation. JORC Code System can be applied for all mineral resources, while there are special JORC guidelines for estimating and reporting coal deposits as resources and reserves [8,9]. International classifications, especially the JORC code, pay special attention to the way the data on reserves and their formal availability for exploitation are presented. The documentation of a deposit, following the guidelines of the international classification of resources approved by JORC code, is to provide information to what extent the deposits are explored, their economic feasibility and the progress of their development in given conditions of market economy [10-13].

Under the current market conditions, the classification of mineral resources should provide information for investors about the degree of resource recognition and level of confidence, economic assessment and the possibility of exploitation. In order to achieve this, every effort should be made to develop a Polish code for estimation mineral 
resources similar to the JORC code, as Russia has done by issuing its own code for the international classification of mineral resources named NAEN Code [14]. Comparison of both classifications and amount of the hard coal resources in Upper Silesian Coal Basin according to polish standards and JORC Code are presented in a synthetic way in other article [15].

The documented anticipated economic resources in hard coal deposits in Poland, as of 31 December 2018, are 61,436 million metric tons (Table 2). Steam coals constitute $69.6 \%$ of the resources, coking coals $-29.1 \%$, and other types of coal constitute $1.3 \%$ of all the coal resources. The reserves in the developed deposits constitute $36.3 \%$ of anticipated economic resources and they are 22,308 million metric tons [16].

Economic resources of coal mines, determined in deposit development projects, were, as of the end of 2018, 3,605.45 million metric tons. At present, subeconomic resources are referred to in conjunction with the validity period of granted mining licences, thus, their actual volume in some deposits may be much greater [16].

Hard coal deposits in Poland occur in three basins. Hard coal production is currently conducted in two of them: the Upper Silesian Coal Basin (USCB) and the Lublin Coal Basin (LCB). Exploitation of five coal deposits in the Lower Silesian Coal Basin (LSCB) ceased approximately 20 years ago.

The Upper Silesian Coal Basin, with $80.3 \%$ of documented anticipated economic resources of hard coal, is the main basin of Poland. At present, all but one operating coal mines are located in the USCB (Fig. 2). The area of the Upper Silesian Coal Basin in Poland is estimated to be approximately $5,600 \mathrm{~km}^{2}$.

The article presents the results of works concerning evaluation of undeveloped deposits in the Upper Silesian Coal Basin and an estimation of hard coal reserves which can be developed by 2050 . All the results concerning coal deposits refer to the anticipated economic resources following the classification of solid mineral resources applied in Poland.

Evaluation of hard coal deposits was established on criterions choice and their score determination.
There were selected areas of undeveloped deposits, located in direct vicinity of operating mines, which can extend their hard coal reserve base. The anticipated economic resources of selected deposits at the depth of 1,000-1,500 metres were estimated. Moreover, deposit areas were selected and hard coal reserves were estimated with a view to building new coal mines. For selected deposits there were built spatial geological models considering arrangement of coal seams and the structure of the rock mass.

The results of the research presented in this article are important in view of the fact that hard coal has significant role in Polish economy. Knowledge of hard coal reserves and their appraisal can be basis for decision making in supreme authorities of state.

Presented methodology and results of this study may be helpful in studies concerning determination of the areas of deposits that can extend the reserve base of hard coal in active mines, for the selection of prospective areas for development and for the determination of the current reserves of hard coal in the area of USCB.

\section{Materials and Methods}

Estimations of undeveloped deposits, as objects qualifying for prospective development, are a complex issue. Attempts to estimate deposits are usually based on scoring basic qualities of a deposit or basic aspects associated with its development. The total of all the points scored by given deposits may form the basis for the classification of the analysed deposits [17-19].

The starting point is choosing estimation criteria. In the paper, the applied spatial criterion, which determines if a deposit is accessible or not, is the location of an undeveloped deposit in the vicinity of an operating mine. Another group of criteria includes the volume of coal resources in the deposit, main types of coal in a deposit, together with geological and mining conditions which characterize given deposits. The conditions include possible exploitation hazards such as: coal dust explosion hazard, water hazard, methane hazard, fire hazard, rock burst hazard, gas and rock outburst hazard. The analysed environmental criteria include the degree of urbanisation of the surface, occurrence

Table 2. Hard coal deposits and resources in Poland [16].

\begin{tabular}{lllllll}
\hline Region & \multicolumn{2}{l}{ Geological resources [million metric tons] } & \multirow{2}{*}{ Economic } & \multicolumn{2}{c}{ Number of deposits } \\
\cline { 2 - 3 } \cline { 5 - 6 } & Anticipated economic & Anticipated sub-economic & & & Total & Exploited deposits \\
\hline Upper Silesian Coal Basin & 49,351 & 14,546 & 3,074 & 144 & 42 \\
Lublin Coal Basin & 11,662 & 5,093 & 531 & 10 & 1 \\
Lower Silesian Coal Basin & 424 & 37 & - & 7 & - \\
\hline Poland & 61,436 & 14,546 & 3,605 & 161 & 43 \\
\hline
\end{tabular}




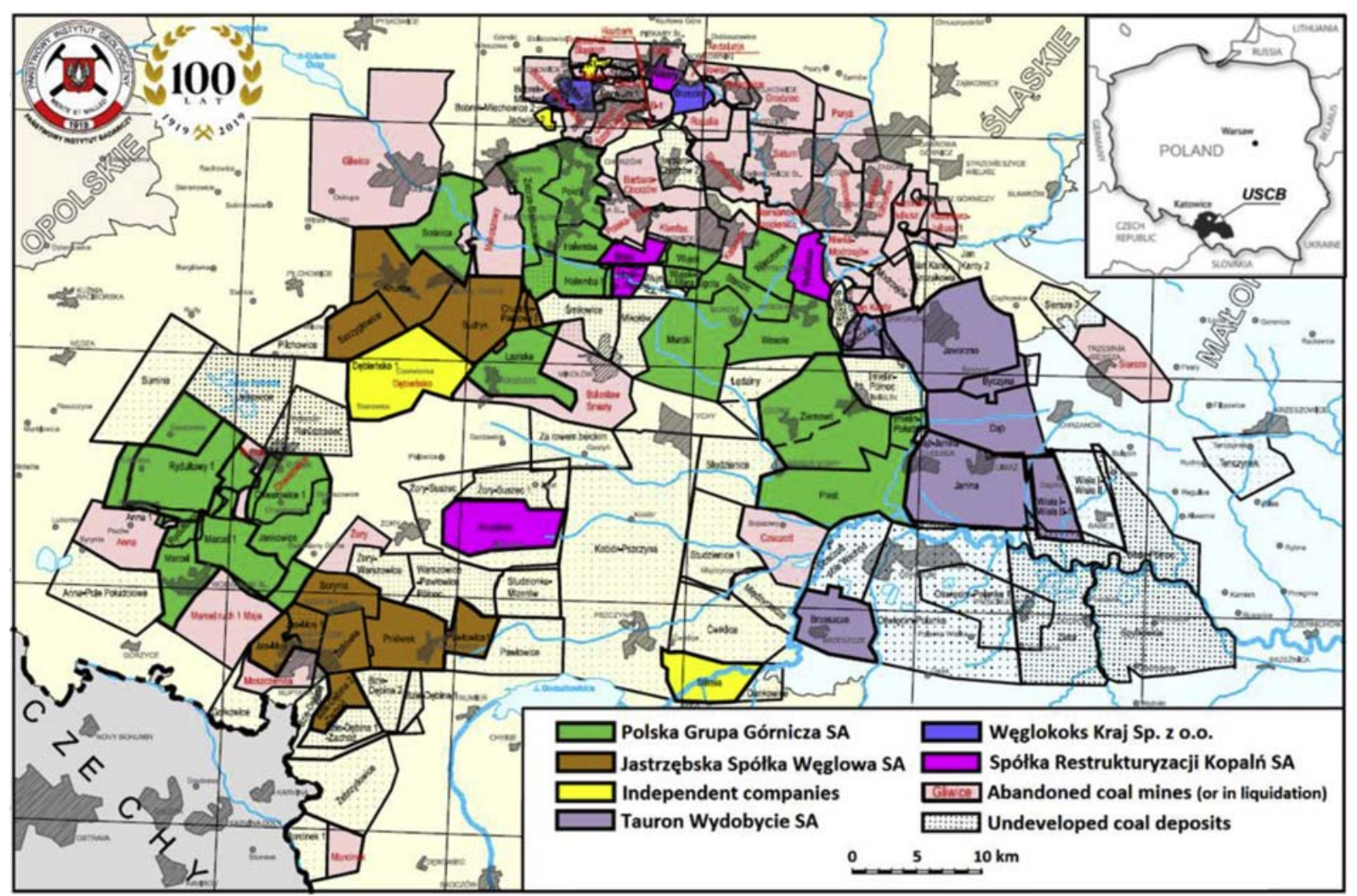

Fig. 2. Map of distribution and development of hard coal deposits of the Upper Silesian Coal Basin as of 31 December 2018 ([16], modified).

of protected objects and other vulnerable elements of the environment, as well as possible environmental hazard associated with mineral extraction and processing. Table 3 presents the assumed estimation criteria together with the point scale attributed to given features of a deposit.

While estimating the undeveloped deposits with a view to the presence of protected objects and other vulnerable elements of the environment, it was analysed whether there are present any components of the environment which are protected by law such as nature reserves, Nature 2000 areas, landscape parks and other forms of environmental protection, as well as forests which cover over $50 \%$ of the deposit area (Fig. 3).

Following the assumed methodology, there were selected areas of undeveloped deposits adjacent to operating mines whose reserves they may extend. Applying Petrel Schlumberger software [21], for selected deposits there were built 3D geological models.

Basic input material applied to build a 3D lithological model of the deposit included lithological data from boreholes. The lithofacies from the available core profiles were given numerical codes.
Then, such processed data were implemented in the structural model which had been prepared before. The results of well logs, in discrete form, were scaled up.

Statistical algorithm Most of, which assigns a given interval to a lithological type which is the most common in the averaging interval, was applied for the lithological data. Accuracy of matching the average data in the model depends mainly on the vertical resolution of the model, i.e. its division into litho-stratigraphic layers. To build a lithological model, Sequential Indicator Simulation algorithm, belonging to a group of stochastic algorithms, was applied. Detailed construction of the 3D geological model of Oświęcim-Polanka deposit and possibility of employing it in the project of the deposit development were discussed in our previous work [22].

During the next stage, there was prepared a database of boreholes in the area of deposits of selected operating mines. There were prepared coal-bearing potential maps, and anticipated economic resources in selected deposits at the depth of $1,000-1,500$ metres were calculated.

Finally, there was selected a potential deposit area with a view to building a new hard coal mine in the 
Table 3. Estimation criteria for undeveloped deposits.

\begin{tabular}{|c|c|c|c|}
\hline ID & Criterion & Range & Point scale \\
\hline \multicolumn{4}{|c|}{ Spatial criterion determining accessibility of deposit } \\
\hline P1 & Deposit location & Undeveloped deposits, adjacent to mined deposits & 1 \\
\hline \multicolumn{4}{|c|}{ Geological, resource and mining criteria } \\
\hline \multirow[t]{11}{*}{ G1 } & Volume of resources [million metric & $0-20$ & 0 \\
\hline & tons] & $20-40$ & 2 \\
\hline & & $40-60$ & 4 \\
\hline & & $60-80$ & 6 \\
\hline & & $80-100$ & 8 \\
\hline & & $100-120$ & 10 \\
\hline & & $120-140$ & 12 \\
\hline & & $140-160$ & 14 \\
\hline & & $160-180$ & 16 \\
\hline & & $180-200$ & 18 \\
\hline & & $>200$ & 20 \\
\hline \multirow[t]{2}{*}{ G2 } & Main types of coal in the deposit & Steam coals & 0 \\
\hline & & Coking and special coals & 2 \\
\hline \multirow[t]{2}{*}{ G3 } & Geological and mining conditions & Very difficult & 0 \\
\hline & & Difficult & 1 \\
\hline \multicolumn{4}{|c|}{ Environmental criteria } \\
\hline & Effects of deposit exploitation on the & Highly urbanised areas (compact building design) & 0 \\
\hline \multirow[t]{3}{*}{ S1 } & surface & $\begin{array}{l}\text { Areas of medium degree of urbanisation (dispersed } \\
\text { development, important transportation infrastructure) }\end{array}$ & 1 \\
\hline & & Lowly urbanised areas (farming areas and forests) & 2 \\
\hline & $\begin{array}{l}\text { Protected objects and other vulnerable } \\
\text { elements of environment }\end{array}$ & $\begin{array}{l}\text { Nature reserves, Nature } 2000 \text { areas, forests covering over } \\
50 \% \text { of deposit area }\end{array}$ & 0 \\
\hline \multirow[t]{2}{*}{ S2 } & & $\begin{array}{l}\text { No protected objects, no forests covering over } 50 \% \text { of } \\
\text { deposit area }\end{array}$ & 2 \\
\hline & Possible environmental hazards caused & No hazards indicated or fewer than three hazards & 1 \\
\hline S3 & by extraction and processing minerals & $\begin{array}{l}\text { More than three hazards (including: mass wasting, } \\
\text { subsidences, flooding, surface deformations, noise, rock } \\
\text { bursts, dust, disturbed water environment in the rock } \\
\text { mass, air pollution, water salinity, emission of coal } \\
\text { preparation chemicals, ground water pollution) }\end{array}$ & 0 \\
\hline
\end{tabular}

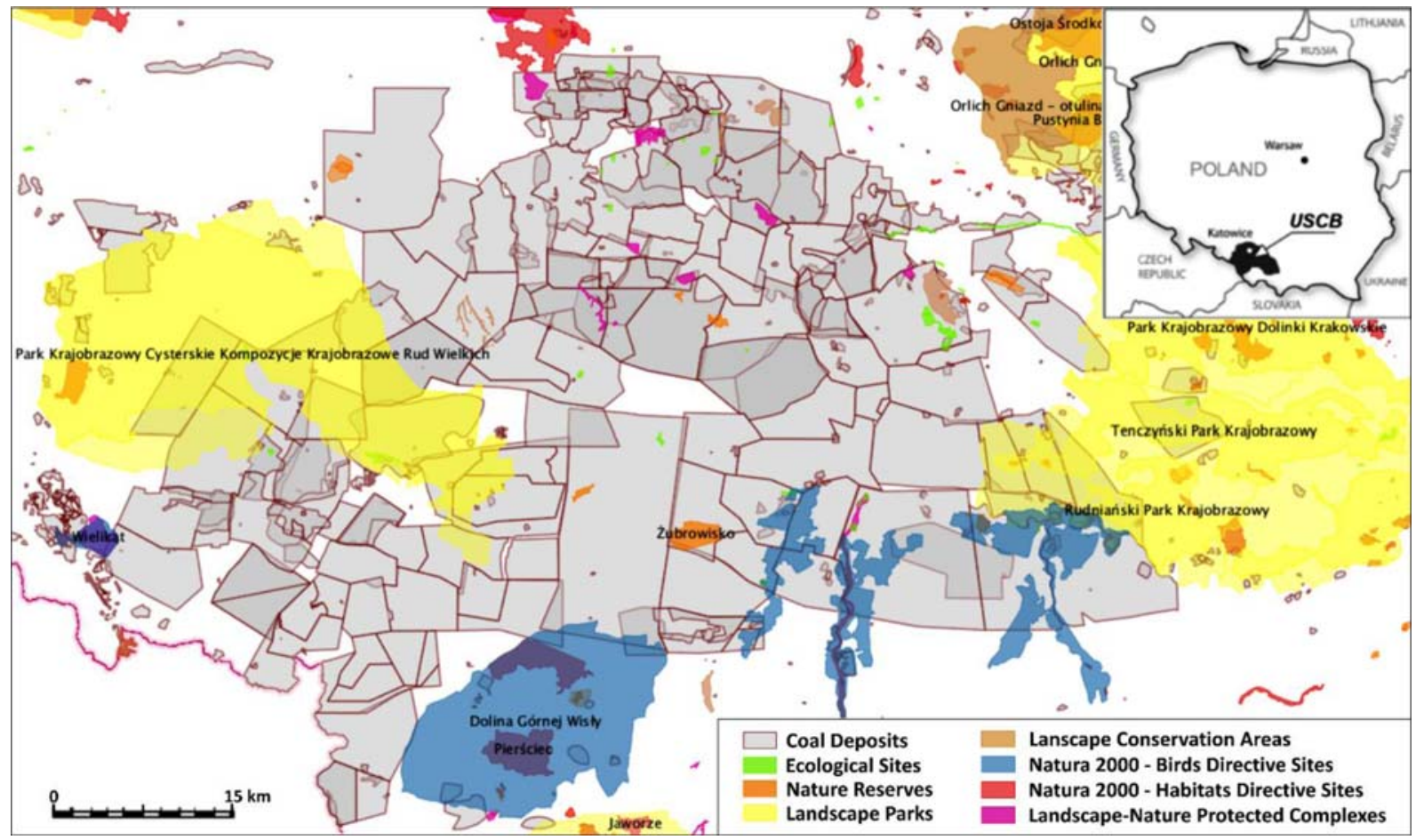

Fig. 3. Forms of nature protection and other vulnerable important elements of the environment [20]. 
USCB. There was built a 3D geological model of the deposit which included arrangement of coal seams and the structure of the rock mass.

\section{Results and Discussion}

\subsection{Initial classification of undeveloped deposits}

During the initial analysis of undeveloped deposits, the ones of anticipated economic resources which fall only into category D of deposit verification (Pilchowice, Studzionka-Mizerów, Sumina) were excluded from the further procedure of deposit estimations. These are undeveloped deposits with prognostic/perspective hard coal resources tentatively recognized in category $\mathrm{D}$ with error in estimating the average values of the deposit parameters and amount of resources which may exceed $40 \%$ [23].

Moreover, coal deposits with indicated anticipated economic resources lower than 40 million metric tons of coal (Anna-Pole Południowe, Barbara-Chorzów 2, Jan Kanty 2, Libiąż-Janina) were excluded from further analyses as well. Undeveloped deposits with relatively small prognostic/ perspective estimated reserves of coal may only be relevant in the case when their highest resourceful parts are directly adjacent to the mined deposits. However, it requires increasing the degree of geological recognition and individual in-depth analysis of coal deposit.

As a result, there were 44 undeveloped deposits left which qualified for further analyses. The anticipated economic resources in given deposits are presented in Table 4.

\subsection{Estimation of undeveloped deposits}

In accordance with the assumed multi-criteria methodology for estimating undeveloped deposits, the scoring scale presented in Table 3 was used to assess the deposits. The selected deposits were analysed with a view to their potential use for future development. The final scores of the deposits are collected in Table 5 .

As a result of the analyses of the deposits, considering geological and resource, mining, spatial and environmental aspects; there were selected seven deposits which scored the highest. The deposits and notes concerning their prospective development are presented in Table 6 .

In the areas of the undeveloped deposits (Śmiłowice, Imielin Północ and Paruszowiec), it was
Table 4. Initial classification of undeveloped deposits [16].

\begin{tabular}{|c|c|c|}
\hline \multirow[t]{2}{*}{ Deposit } & \multicolumn{2}{|c|}{$\begin{array}{l}\text { Geological resources } \\
\text { [thousand tons] }\end{array}$} \\
\hline & $\begin{array}{l}\text { anticipated } \\
\text { economic } \\
\text { resources }\end{array}$ & $\begin{array}{l}\text { sub-economic } \\
\text { resources }\end{array}$ \\
\hline Brzezinka & 44,130 & 8,515 \\
\hline Brzezinka-2 & 320,520 & 48,916 \\
\hline Brzezinka-3 & 90,760 & - \\
\hline Bzie-Dębina 1 & 122,236 & 62,638 \\
\hline Bzie-Dębina 1 - Zachód & 404,608 & - \\
\hline Bzie-Dębina 2 & 347,580 & - \\
\hline Bzie-Dębina 2 - Zachód & 322,404 & 44,906 \\
\hline Czeczott -Wschód & 434,914 & 185,180 \\
\hline Ćwiklice & 499,332 & 94,138 \\
\hline Dankowice & 115,684 & 13,914 \\
\hline Dąb & $1,085,873$ & - \\
\hline Gołkowice & 77,078 & 154,978 \\
\hline Imielin Północ & 766,228 & - \\
\hline Jan Kanty - Szczakowa & 146,531 & - \\
\hline Jejkowice & 166,245 & 93,971 \\
\hline Kobiór-Pszczyna & $3,063,506$ & $1,888,638$ \\
\hline Lędziny & 140,586 & 87,831 \\
\hline Marcel 1 & 266,054 & - \\
\hline Mięzdzyrzecze & 368,683 & 183,563 \\
\hline Mikołów & 198,518 & 153,961 \\
\hline Modrzejów & 46,505 & 140 \\
\hline Morcinek 1 & 591,368 & 60,738 \\
\hline Oświęcim-Polanka & $2,142,426$ & - \\
\hline Oświęcim-Polanka 1 & 534,002 & - \\
\hline Paruszowiec & 486,337 & - \\
\hline Pawłowice & 414,263 & 85,629 \\
\hline Powstańców Śląskich 1 & 48,021 & - \\
\hline Rydułtowy 1 & $1,158,570$ & - \\
\hline Siersza 2 & 202,035 & - \\
\hline Spytkowice & 662,614 & 37,352 \\
\hline Studzienice & 327,106 & 134,290 \\
\hline Studzienice 1 & $1,335,563$ & - \\
\hline Śmiłowice & 737,620 & - \\
\hline Tenczynek & 64,543 & 13,621 \\
\hline Warszowice-Pawłowice Płn. & 162,961 & 117,500 \\
\hline Wisła I - Wisła II & 822,766 & 84,432 \\
\hline Wisła Północ & 303,969 & 6,196 \\
\hline Wujek-część południowa & 253,428 & \\
\hline Za rowem bełckim & 342,502 & 103,010 \\
\hline Zator & 708,645 & - \\
\hline Zebrzydowice & 108,439 & 59,956 \\
\hline Żory-Suszec & 888,173 & 63,964 \\
\hline Żory-Suszec 1 & 542,623 & - \\
\hline Żory-Warszowice & 151,916 & 93,680 \\
\hline
\end{tabular}

concluded that it is possible to develop and exploit them. The selected deposits are located in the direct vicinity of operating mines and they can extend their hard coal reserves.

Paruszowiec deposit is considered to be the most promising with a view to possible development, 
Table 5. Results of estimation of undeveloped deposits.

\begin{tabular}{|c|c|c|c|c|c|c|c|c|}
\hline \multirow[t]{3}{*}{ Deposit } & \multicolumn{7}{|c|}{ Criterion ID } & \multirow[t]{3}{*}{ Total } \\
\hline & \multirow{2}{*}{$\frac{\text { spatial }}{\mathrm{P} 1}$} & \multicolumn{3}{|c|}{ resource, geological and mining } & \multicolumn{3}{|c|}{ environmental } & \\
\hline & & G1 & G2 & G3 & S1 & S2 & S3 & \\
\hline Śmiłowice & 1 & 20 & 2 & 1 & 2 & 2 & 1 & 29 \\
\hline Bzie-Dębina 1 - Zachód & 1 & 20 & 2 & 0 & 2 & 2 & 1 & 28 \\
\hline Ćwiklice & 1 & 20 & 0 & 1 & 2 & 2 & 1 & 27 \\
\hline Pawłowice & 1 & 20 & 2 & 0 & 2 & 0 & 1 & 26 \\
\hline Imielin Północ & 1 & 20 & 0 & 0 & 2 & 2 & 0 & 25 \\
\hline Paruszowiec & 1 & 20 & 0 & 1 & 2 & 1 & 0 & 25 \\
\hline Bzie-Dębina 2 & 1 & 16 & 2 & 1 & 1 & 2 & 1 & 24 \\
\hline Czeczott-Wschód & 1 & 20 & 0 & 1 & 1 & 0 & 1 & 24 \\
\hline Brzezinka-2 & 1 & 16 & 0 & 0 & 1 & 2 & 0 & 20 \\
\hline Studzienice & 1 & 16 & 0 & 1 & 0 & 2 & 0 & 20 \\
\hline Marcel 1 & 1 & 12 & 2 & 1 & 2 & 2 & 0 & 20 \\
\hline Wujek-część południowa & 1 & 12 & 0 & 1 & 1 & 2 & 1 & 18 \\
\hline Mikołów & 1 & 8 & 2 & 1 & 1 & 2 & 1 & 16 \\
\hline Bzie-Dębina 1 & 1 & 6 & 2 & 1 & 2 & 2 & 1 & 15 \\
\hline Warszowice-Pawłowice Płn. & 1 & 8 & 2 & 0 & 2 & 2 & 0 & 15 \\
\hline Żory-Warszowice & 1 & 6 & 2 & 1 & 2 & 2 & 0 & 14 \\
\hline Centrum 1 & 1 & 10 & 0 & 0 & 0 & 2 & 0 & 13 \\
\hline Jan Kanty - Szczakowa & 1 & 6 & 0 & 1 & 1 & 2 & 0 & 11 \\
\hline Lędziny & 1 & 6 & 0 & 0 & 2 & 2 & 0 & 11 \\
\hline Jas-Mos 1 & 1 & 4 & 2 & 0 & 1 & 2 & 0 & 10 \\
\hline Brzezinka-3 & 1 & 4 & 0 & 0 & 1 & 2 & 1 & 9 \\
\hline Brzezinka & 1 & 2 & 0 & 1 & 0 & 2 & 1 & 7 \\
\hline Dankowice & 1 & 4 & 0 & 1 & 0 & 0 & 0 & 6 \\
\hline Powstańców Śląskich 1 & 1 & 2 & 0 & 0 & 0 & 2 & 1 & 6 \\
\hline
\end{tabular}

hence there was built a spatial geological model for the area including the arrangement of coal deposits and the structure of the rock mass (Fig. 4). The software applied to build the static model of Paruszowiec hard coal deposit was Schlumberger Petrel version 2010.1 [21].

The structural model of Paruszowiec deposit was built with the use of data from the documentation and the deposit development project. The model was supplemented with the following structural elements: isolines of floors of given seams, isolines of the roof of the Carboniferous layer, isopach maps, faults, borehole data, and planned seam exploitation.

The model presents the arrangement of coal seams together with designed longwalls (Fig. 5). The model includes the following coal seams: 416,418 , $501,502 / 3,502 / 4,503,504+505,506$.

\subsection{Selection of areas of deposits which can extend reserves of operating mines (up to the depth of 1,500 metres)}

Undeveloped deposit Lędziny was selected as a potential deposit whose resources could be included in the reserves of operating mines, up to the depth of 1,500 metres. Lędziny deposit is located within the mining areas of Piast-Ziemowit Ruch Ziemowit coal mine and Mysłowice-Wesoła Ruch Wesoła coal mine. The anticipated economic resources of hard coal in Lędziny deposit documented up to the depth of 1,000 metres, in

Table 6. Final results of valorisation of undeveloped deposits.

\begin{tabular}{lll}
\hline Deposit & Total pts & Notes \\
\hline Śmiłowice & 29 & Possible development of the deposit \\
Bzie-Dębina 1 - Zachód & 28 & Significant thickness of the overburden above the deposit - high costs of deposit development \\
Ćwiklice & 27 & The deposit adjacent to private Silesia coal mine \\
Pawłowice & 26 & Ongoing development works in Pawłowice 1 deposit (exploitation until approx. 2050) \\
Imielin Północ & 25 & Possible development of the deposit \\
Paruszowiec & 25 & Possible development of the deposit \\
\hline
\end{tabular}




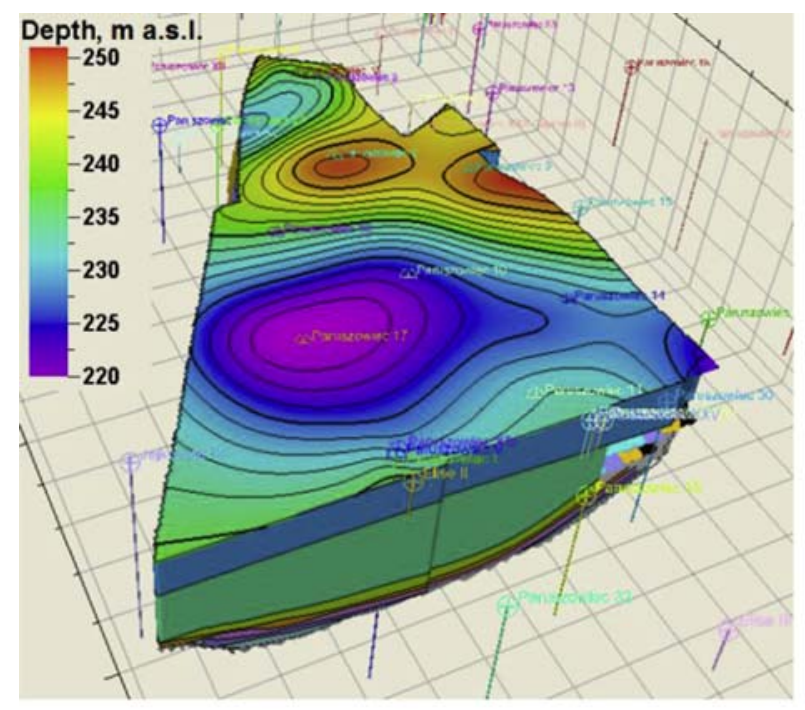

(a)

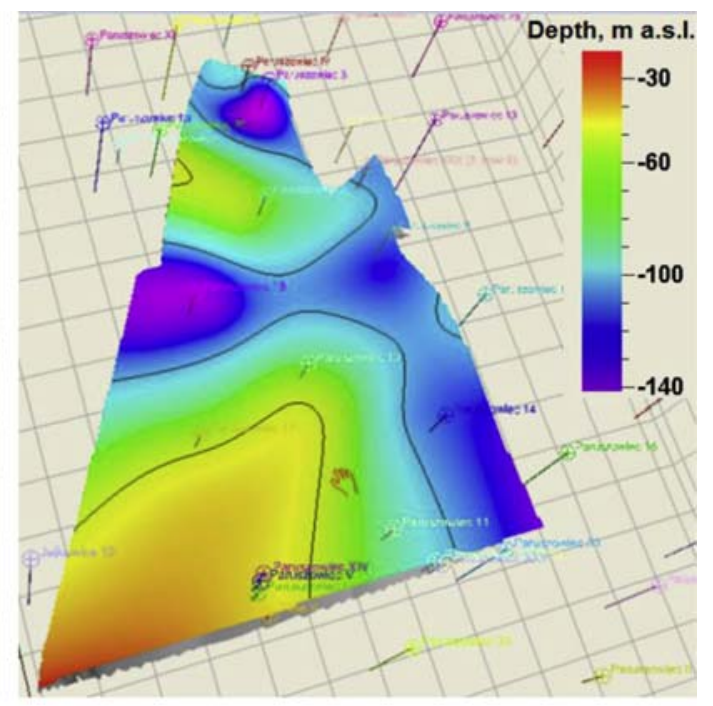

(b)

Fig. 4. Model of Paruszowiec deposit: (a) land surface; (b) the top of Carboniferous layer.

category C1, C2 are 140,586 thousand metric tons [16].

Coal reserves in Lędziny deposit at the depth $1,000-1,500$ metres were estimated. The calculations employed a coal-bearing potential method in which the total thickness of over-1-metre-thick coal seams in a deposit, is calculated and then, on the basis, a map of isolines of total coal thickness in the vertical profile of the deposit is drawn, and anticipated economic resources at the depth of $1,000-1,500$ metres are estimated.

At the first stage of works within Lędziny deposit, a 3D map (grid) of coal-bearing potential distribution was prepared by processing data collected in the data base. In the area of Ledziny deposit, to visualise it better the isoline, a coalbearing potential map was interpolated (Fig. 6).

Then, the demanded parameters of the mineral were calculated: the surface area of the deposit, its volume; maximum, minimum and average coalbearing potential in the area of coal deposit. The data, in text form, were exported to the database for reserve calculations.

The anticipated economic resources of hard coal in Lędziny deposit were calculated basing on the obtained numerical data and assuming averaged

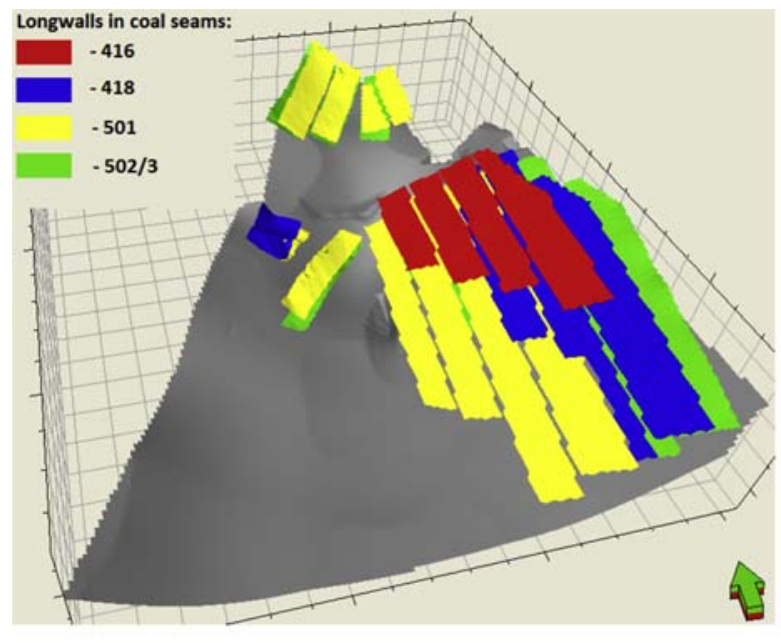

(a)

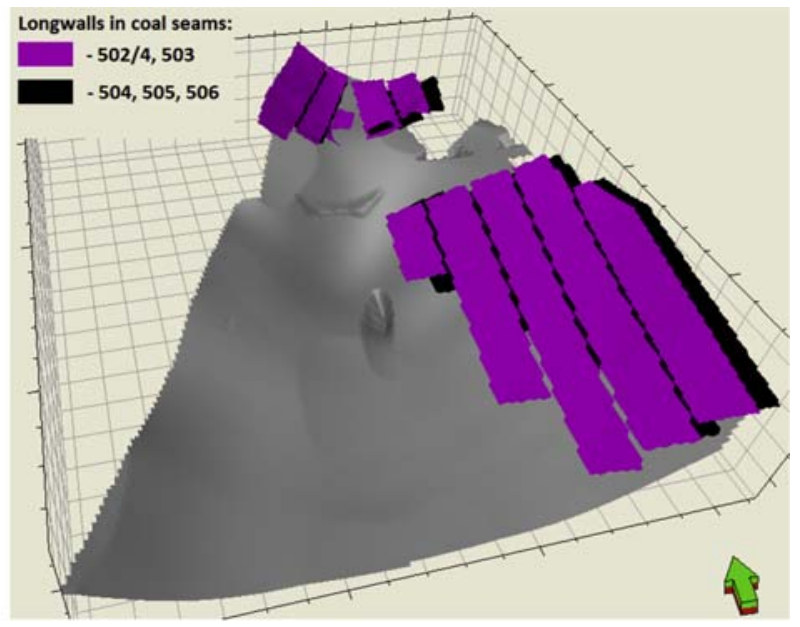

(b)

Fig. 5. Model of Paruszowiec deposit: (a) designed longwalls in seams 504, 505, 506; (b) planned exploitation in seam 502/4, 503. 


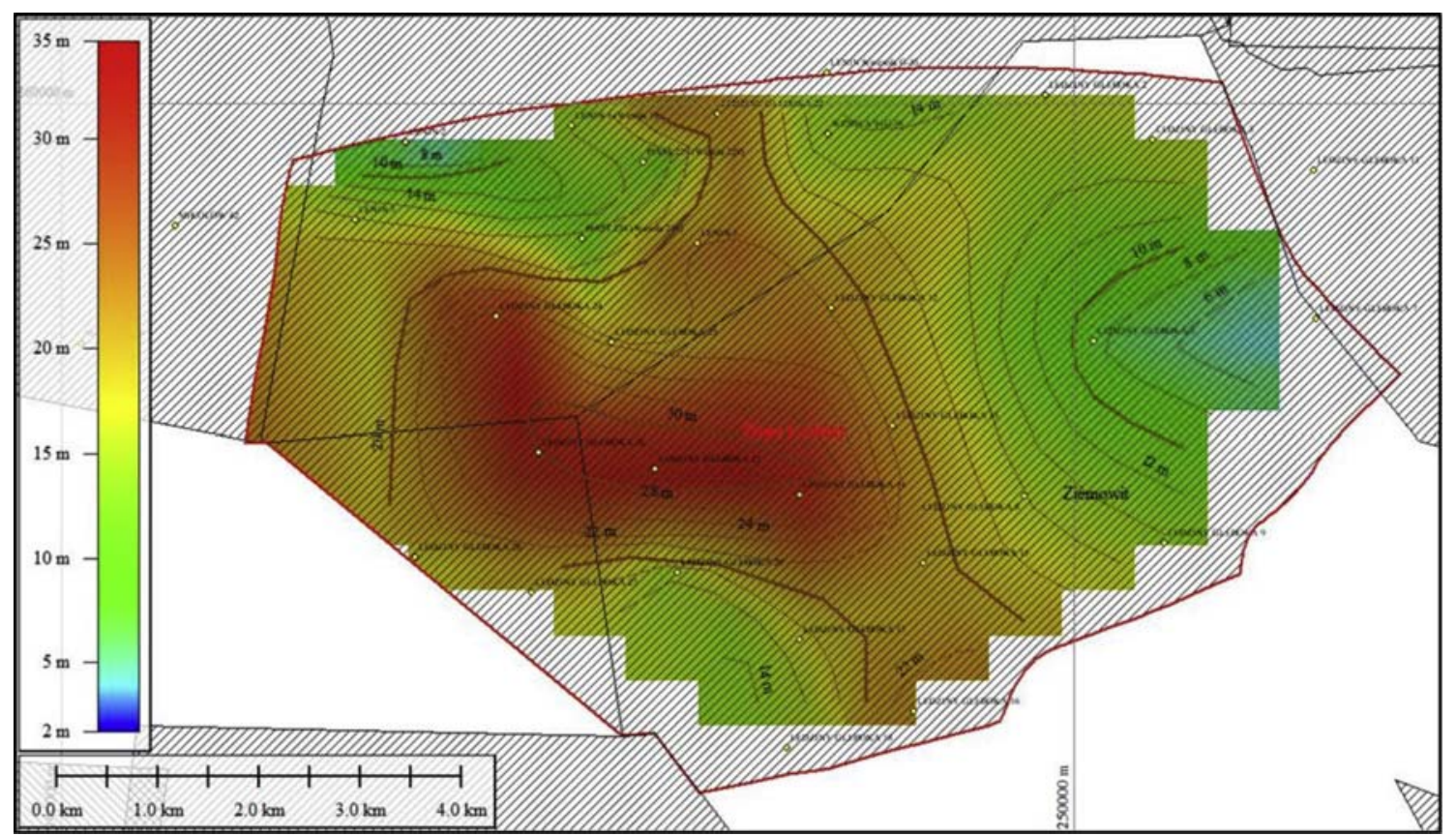

Fig. 6. Isoline coal-bearing potential map of Lędziny deposit.

unit weight of coal. Hard coal reserves were calculated for the depth of 1,000-1,500 metres, without dividing into more detailed reference levels. Finally, the value of anticipated economic resources in Lędziny deposit at the depth of 1,000-1,500 metres (Table 7) was obtained. The coal-bearing potential means the total thickness of over-1-metre-thick coal seams in coal deposit.

The calculated volume of coal reserves can be analysed in detail at further stages of work by (1)

Table 7. Results of calculations of hard coal reserves in Lędziny deposit (a coal-bearing potential method).

\begin{tabular}{lll}
\hline Parameter & Volume & Unit \\
\hline $\begin{array}{l}\text { Surface area of coal } \\
\text { deposit }\end{array}$ & $47,668,186$ & $\mathrm{~m}^{2}$ \\
$\begin{array}{l}\text { Minimal coal-bearing } \\
\text { potential in the area of } \\
\text { coal deposit }\end{array}$ & 4.2 & $\mathrm{~m}$ \\
$\begin{array}{l}\text { Maximal coal-bearing } \\
\text { potential in the area of } \\
\text { coal deposit }\end{array}$ & 33.4 & $\mathrm{~m}$ \\
$\begin{array}{l}\text { Average coal-bearing } \\
\text { potential in the area of } \\
\text { coal deposit }\end{array}$ & $\sim 18.5$ & \\
$\begin{array}{l}\text { Volume of coal deposit } \\
\quad \text { Surface area* Average } \\
\quad \text { coal-bearing potential) }\end{array}$ & $881,956,671$ & $\mathrm{~m}$ \\
$\begin{array}{l}\text { Specific gravity of coal } \\
\text { Estimated anticipated }\end{array}$ & 1.3 & \\
$\quad$ economic resources, \\
$\quad$ depth of 1,000 & $1,146,543.7$ & $\mathrm{t} / \mathrm{m}^{3}$ \\
$\quad-1,500$ metres & & \\
\hline
\end{tabular}

dividing into 100-metre-thick exploitation levels, (2) dividing into reserves within mining areas of operating coal mines and in areas kept in reserve or (3) selecting resources deposited within borders of local administrative units.

\subsection{Selection of areas of deposits and the volume of deposits with a view to building new mines in the USCB area}

Building new coal mines is a very complicated issue. It involves deep analysis of market offer and demand, substitution possibility of hard coal and economic evaluation. Regarding vastness of that issue, it can be considered in detail at situation on market and society, when new mines building will be necessary and admissible.

Moreover, when the areas to build new hard coal mines are selected, environmental and social aspects play a significant role. In many cases, social approval of the planned mineral extraction from a deposit plays a significant role when an investor decides to realize a mining project. One of the tools which enables initial estimation of deposits with a view to a social conflict associated with environmental issues is the mathematical multicriteria method AHP (Analytic Hierarchy Process) [24,25]. Basing on the analysis of 15 deposits, conducted with multicriteria method AHP [26], the area which can be considered to be least vulnerable to a social and environmental conflict, is a fragment of 


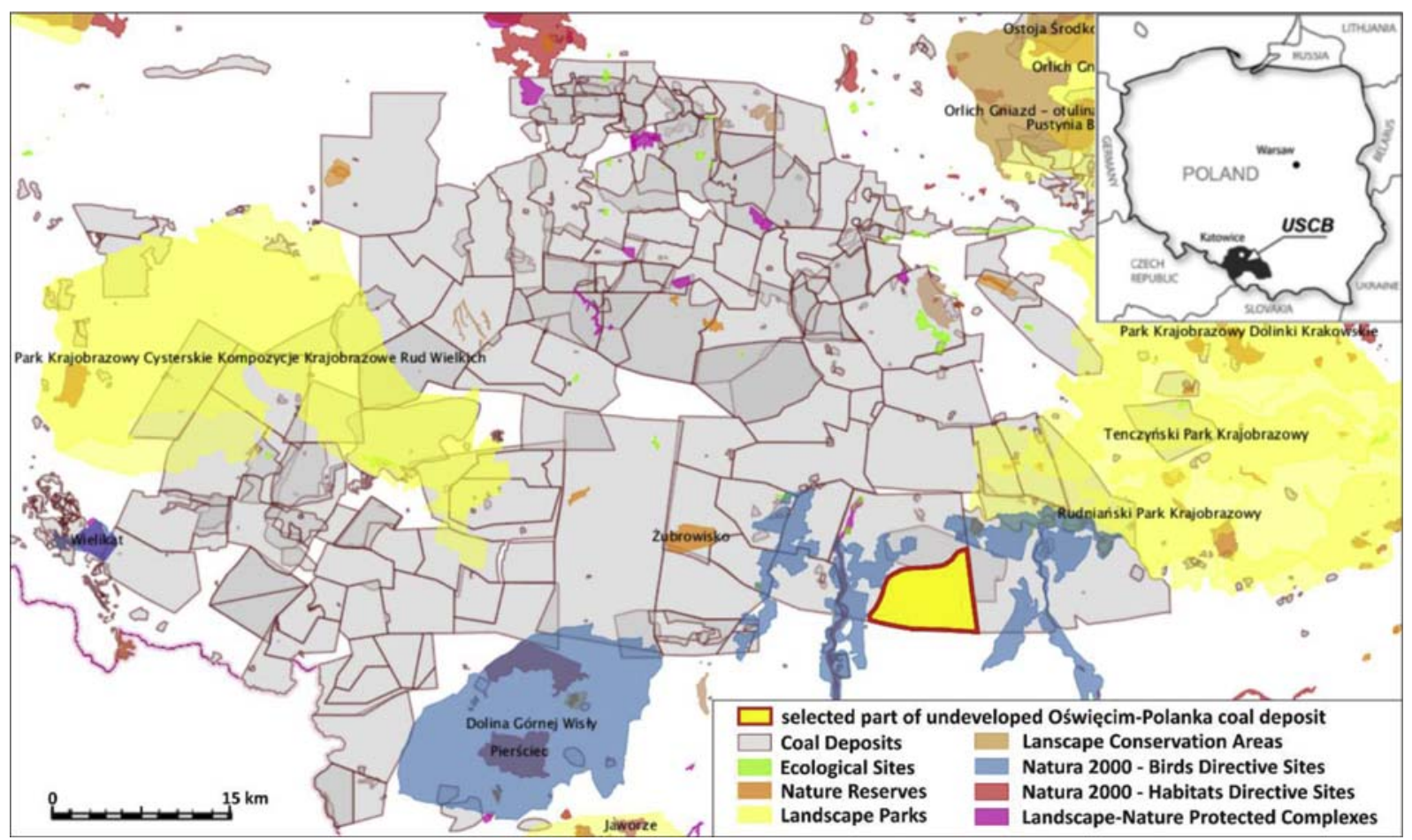

Fig. 7. Location of a part of Oświęcim-Polanka deposit considered [20].

undeveloped Oświęcim-Polanka deposit (Fig. 7). The map below presents clearly that there is no conflict between the selected area and the forms of the environmental protection in the area.

As it has been already mentioned, the area which can be considered to be the least vulnerable to a social and environmental conflict is a fragment of undeveloped Oświęcim-Polanka deposit. However, when the deposit is treated as a whole, it turns out to

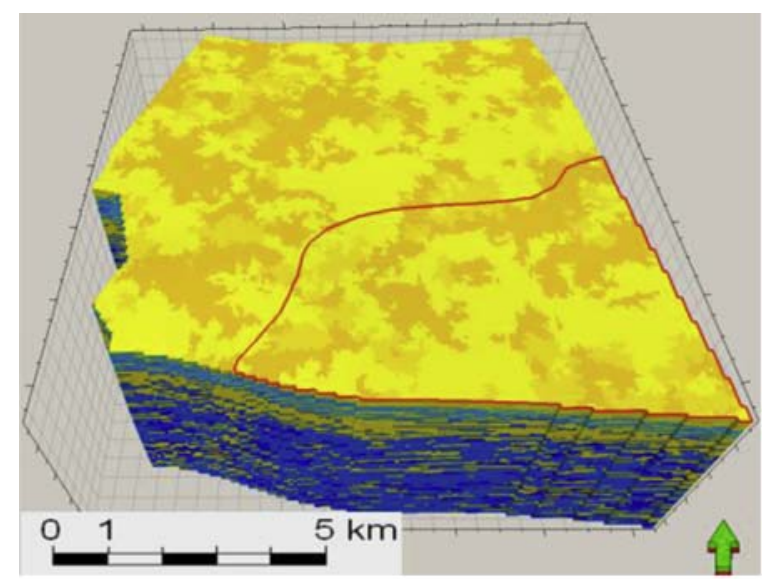

(a) be an area particularly vulnerable to a social and environmental conflict.

For the needs of the analysis, a part of the deposit of the lowest influence of social and environmental conditions was separated out from earlier developed model (Fig. 8).

One of the ways of developing a deposit is driving underground roadways connecting coal seams with the surface $[27,28]$. Fig. 9. presents an example of

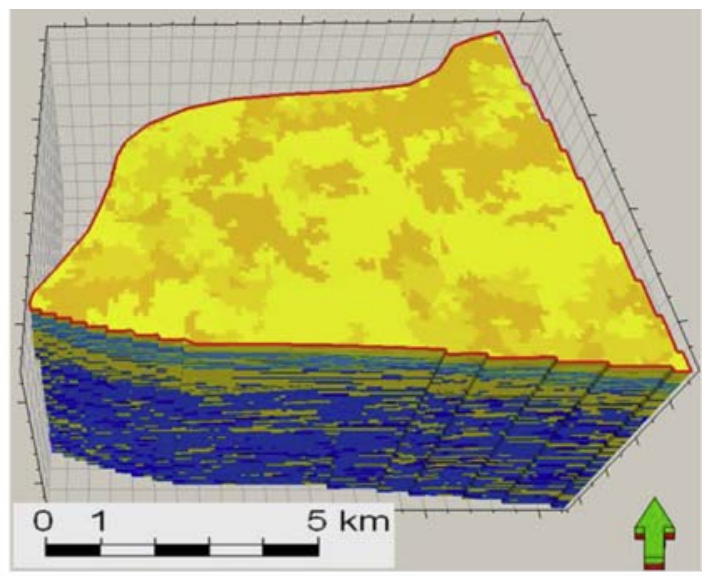

(b)

Fig. 8. 3D model of Oświęcim-Polanka deposit (a) and the selected part of the deposit which is the least vulnerable to a social and environmental conflict (b). 


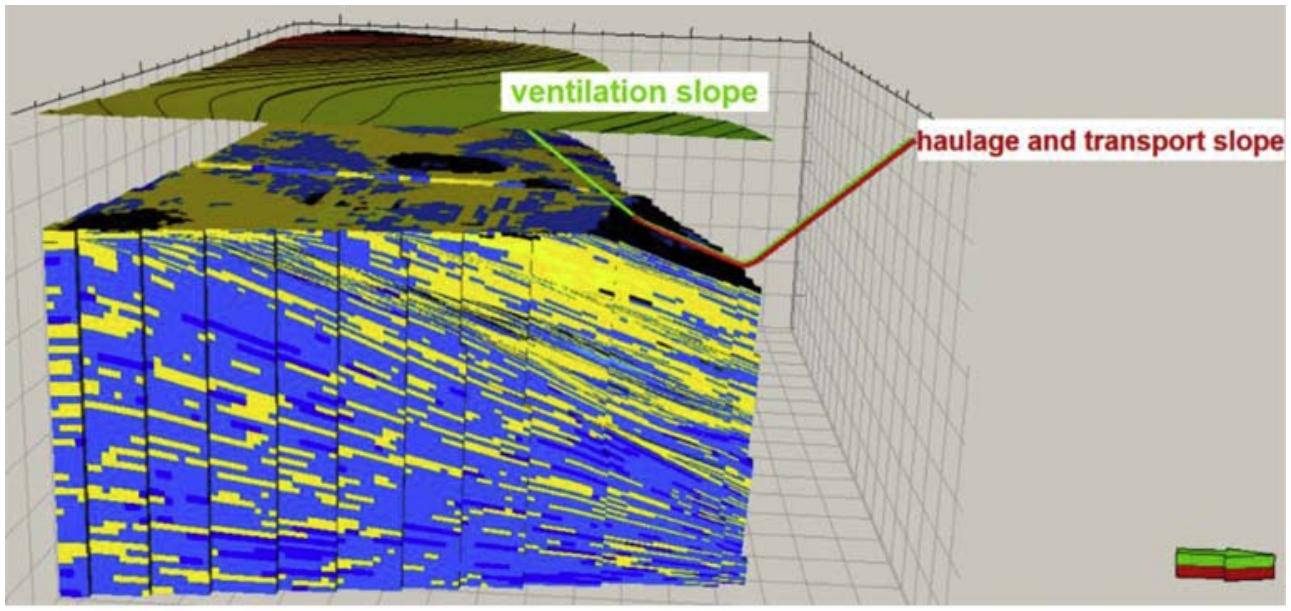

(a)

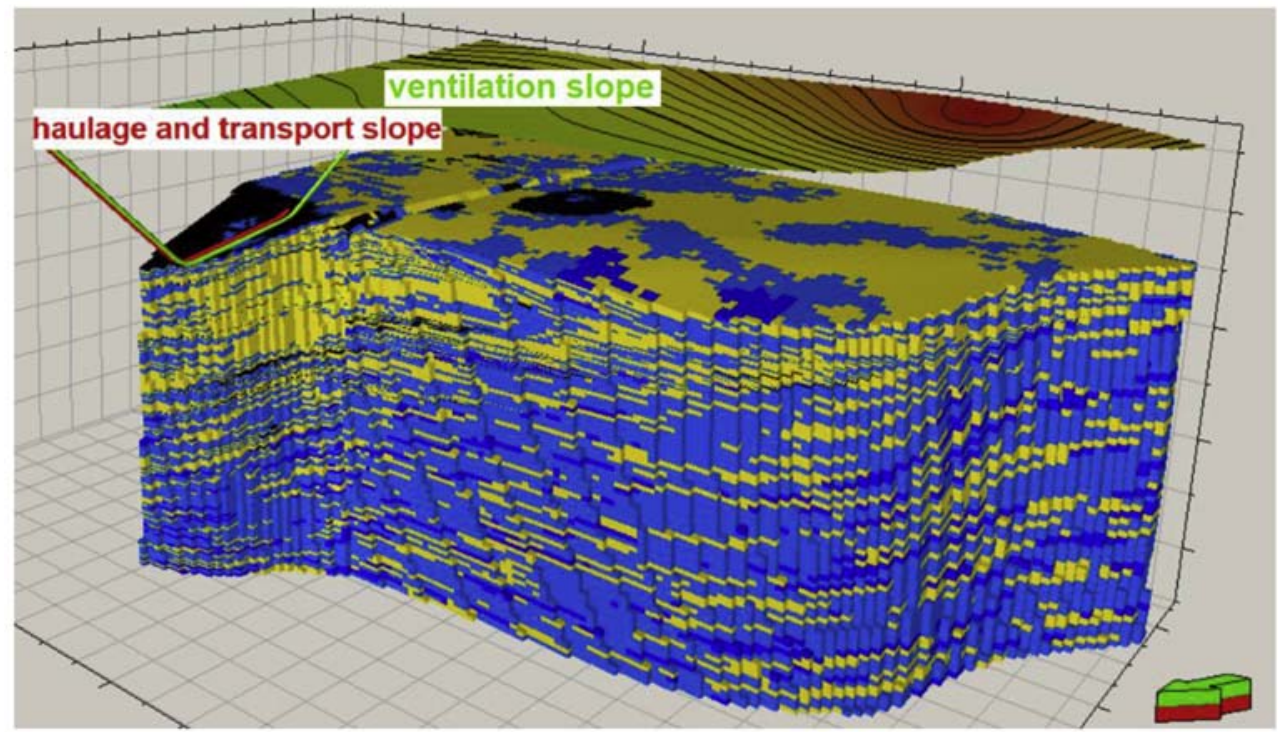

(b)

Fig. 9. Model of developing a part of the deposit: (a) E view; (b) $N-W$ view.

a deposit development with three inclines: ventilation, extraction and transport/haulage. The designed mine working was placed in the 3D geological deposit model which is a useful tool for designing spatial deposit management [29-31].

The anticipated economic resources of OświęcimPolanka deposit are: 2,142.426 million metric tons [16], while for the part of Oświęcim-Polanka deposit, selected as a potential area for building a new coal mine, the anticipated economic resources of hard coal are 924.391 million metric tons.

\section{Conclusions}

Estimations of undeveloped deposits, as objects qualifying for prospective development, are a complex issue. Within the framework of this study, evaluation of hard coal deposits was established on criterions choice and their score determination. On the basis of obtained the final score and after consultations with experts in the field of hard coal mining, there were selected the following areas of undeveloped deposits which can extend the coal reserve base located in the direct vicinity of operating hard coal mines: Śmiłowice deposit with the amount of $737.620 \mathrm{Mt}$ (million metric tons) of anticipated economic resources, Imielin Północ deposit with the amount of $766.228 \mathrm{Mt}$ and Paruszowiec deposit - $486.337 \mathrm{Mt}$. Undeveloped deposit Lędziny was selected as a potential deposit whose resources could be included in the reserves of operating mines, up to the depth of 1,500 metres. 
Anticipated economic resources of a selected Lędziny deposit which can extend hard coal reserve base of coal mines at the depth 1,000-1,500 m amounts to 1,146.544 million metric tons.

Additionally, there were determined areas of the deposits and hard coal reserves were estimated with a view to building new mines. For OświęcimPolanka deposit, there was built a 3D geological model with estimated the amount of $924.391 \mathrm{Mt}$ (million metric tons) of anticipated economic resources of coal. The developed 3D geological models of selected hard coal deposits can be applied to plan deposit development and its rational management. Three dimensional geological model enables effective interpretation of the geological conditions of coal deposit, which may support the mine designing stage. It can also support planning mining operations and protecting the surface against mining subsidence. 3D geological model of a deposit is a tool of growing significance and it is more and more commonly used in rational deposit management.

\section{Conflicts of interest}

None declared.

\section{Ethical statement}

Authors state that the research was conducted according to ethical standards.

\section{Funding body}

This research was conducted within the framework of statutory research no. 11112018-122 of Central Mining Institute's Department of Geology and Geophysics (Katowice, Poland) funded by the Polish Ministry of Science and Higher Education.

\section{References}

[1] BP Statistical Review of World Energy 2016 - 65th Edition. Available online: www.bp.com/statisticalreview.

[2] BGR Energy Study. Federal Institute for Geosciences and Natural Resources. Data and Developments Concerning German and Global Energy Supplies, vol. 22; 2019. p. 174. Hannover.

[3] Geological and Mining Law, Act of 9 June 2011, O.J. No 163, item 981. Prawo geologiczne i górnicze, Ustawa $\mathrm{z}$ dnia 9 czerwca 2011 r. 2011. Dz. U. Nr 163, poz. 981.

[4] Nieć M. Polska i międzynarodowa ramowa klasyfikacja zasobów (UNFC) złóż kopalin stałych i węglowodorów podobieństwa i różnice (Polish and united nations framework classification of resources (UNFC) - similarities and differences). Górnictwo Odkrywkowe 2009;50(2-3):50-7.

[5] Nieć M. Kryteria geologiczne złoża (kryteria bilansowości) (Geological criteria of a deposit)vol. 160. IGSMiE PAN; 2010. Kraków.
[6] Sobczyk EJ, Saługa PW. Coal Resource Base in Poland from the Perspective of Using the JORC Code. In: Proceedings of the 23rd World Mining Congress. Canada: CIM Journal; 2013. https://doi.org/10.13140/2.1.5119.8724.

[7] JORC Code. Joint Ore Reserves Committee. The JORC code and guidelines. Australasian code for reporting of exploration results, mineral resources and ore reserves. Prepared by the Australasian Institute of Mining and Metallurgy (AusIMM). Australian Institute of Geoscientists and Minerals Council of Australia; 2012.

[8] Coombes J. Practice based competency development: a study of resource geologists and the JORC code system. Retrieved from, https://ro.ecu.edu.au/theses/610/; 2013.

[9] JORC Code. Australian Guidelines for the Estimation and Classification of Coal Resources. In: Prepared by the Guidelines Review Committee on behalf of the Coalfields Geology Council of New South Wales and the. Queensland Resources Council; 2014.

[10] Saługa PW, Sobczyk EJ, Kicki J. Wykazywanie zasobów wegla kamiennego w Polsce zgodnie z JORC Code (Reporting of hard coal reserves and resources in Poland on the basis of the JORC Code). IGSMiE PAN 2015;31:5-30. Kraków.

[11] Kalaitzidis S. National reporting codes for the mineral industry: The case of JORC in Australia. Bulletin of the Geological Society of Greece 2013;47:1628-34. https:// doi.org/10.12681/bgsg.11004.

[12] Goddard I. The JORC Code's international reach and cooperation on Resource and Reserve Reporting through CRIRSCO. The AusIMM Bulletin 2013;3:36-7.

[13] Stoker P, Berry M. The JORC Code - Understanding and complying with the CODE. Brisbane, Australia: AMC Consultants Pty Ltd; 2013. p. 82.

[14] Russian Code for the Public Reporting of Exploration Results, Mineral Resources and Mineral Reserves (NAEN Code). 2011. Available online: https://mrmr.cim.org/media/ 1050/517-naen-2011.pdf.

[15] Chećko J, Rosa M, Urych T, Wątor A. Hard coal resources in the Upper Silesia Coal Basin (Poland) according to polish classification and international JORC code. International Multidisciplinary Scientific GeoConference: SGEM; Albena 2019;19(1.3):323-30. https://doi.org/10.5593/sgem2019/1.3/ S03.041.

[16] Szuflicki M, Malon A, Tymiński M. (red. Bilans zasobów złóż kopalin w Polsce wg stanu na 31.12.2018 r. Praca zbiorowa PSG PIG - PIB. Warszawa: PGI-NRI; 2019. wydawca PIG PIB, ISSN: 2299-4459. Proven reserves of mineable deposits in Poland as of 31 Dec 2018.

[17] Jureczka J, Krieger W, Kwarciński J, Galos K, Szlugaj J, Kamyk J. Studium możliwości ponownego zagospodarowania złóż kopalń węgla kamiennego likwidowanych w procesie restrukturyzacji górnictwa. Warszawa: CAG; 2007.

[18] Jureczka J, Galos K, Krieger W, Szlugaj J. Ranking złóż węgla kamiennego kopalń zlikwidowanych $\mathrm{w}$ procesie restrukturyzacji górnictwa po 1989 r. w aspekcie możliwości ich ponownego zagospodarowania (Ranking of coal deposits of liquidated after years 1989 mines in aspect of their redevelopment). 2007.

[19] Jureczka J, Galos K. Propozycje kryteriów waloryzacji złóż oraz obszarów prognostycznych i perspektywicznych węgla kamiennego pod katem ich ochrony (Proposals of criteria for valorization of deposits and prognostic/perspective areas of hard coal for their protection). Zeszyty Naukowe Instytutu Gospodarki Surowcami Mineralnymi i Energią PAN 2010;79: 289-97.

[20] Geo-System. Geoportal Otwartych Danych Przestrzennych, Maps based on the website. 2020. https://polska.e-mapa.net. [Accessed 16 October 2020].

[21] Schlumberger Petrel Seismic-to-Simulation Software. 2010. version 2010.1.

[22] Urych T, Głogowska M, Warzecha R, Wątor A, Chećko J. 3D model of hard coal deposit and analysis of the possibility of using it to plan deposit management. International 
Multidisciplinary Scientific GeoConference: SGEM; Albena 2019;19(1.3):3-13. https://doi.org/10.5593/sgem2019/1.3/ S03.001.

[23] Rozporządzenie Ministra Środowiska z dnia 01 lipca 2015 r. $\mathrm{w}$ sprawie dokumentacji geologicznej złoża kopaliny, $\mathrm{z}$ wyłączeniem złoża węglowodorów (Dz.U.2015.987 z dnia 2015.07.15), available online:(in polish), http://isap.sejm.gov. $\mathrm{pl} /$.

[24] Sobczyk EJ. Analytic Hierarchy Process (AHP) and Multivariate Statistical Analysis (MSA) in Evaluating Mining Difficulties in Coal Mines. In: 21st World Mining Congress New Challenges and Visions for Mining. Kraków, 7-11 September 2008. London: Taylor \& Francis Group; 2008. p. 329-44. A.A. Balkema Book, London.

[25] Sobczyk EJ, Kicki J, Sobczyk W, Szuwarzyński M. Support of mining investment choice decisions with the use of multicriteria method. Resources Policy 2017;2017. https://doi.org/ 10.1016/j.resourpol.2016.11.012.

[26] Sobczyk EJ, Badera J. The problem of developing prospective hard coal deposits from the point of view of social and environmental conflicts with the use of AHP method. Komitet Zrównoważonej Gospodarki Surowcami Mineralnymi PAN, vol. 29. Instytut Gospodarki Surowcami Mineralnymi i Energią PAN; 2013. https://doi.org/10.2478/gospo2013-0040.
[27] Donnelly C, Rammage G, Donghi M. Alternative excavation methods in undeground coal mining. In: Aziz Naj, Kininmonth Bob, editors. Proceedings of the 2014 Coal Operators' Conference, Mining Engineering. University of Wollongong; 2019. 18-20 February 2019. Retrieved from: https://ro.uow.edu.au/coal/516.

[28] Sibthorpe D. Coal drift construction by tunnel boring machine. In: 15th Australasian Tunnelling Conference 2014: Underground Space - Solutions for the Future. Barton, ACT: Engineers Australia and Australasian Institute of Mining and Metallurgy, 2014. The Australasian Institute of Mining and Metallurgy Publication Series; 2014. p. 671-81. ISBN: 9781925100167.

[29] Luo Z, Liu X, Su J, Wu Y, Liu W. Deposit 3D modeling and application. Journal of Central South University of Technology 2007;14:225-9. https://doi.org/10.1007/s11771-007-0045-9.

[30] Che D, Jia G, Jia Q. Key technology of 3D geosciences modeling in coal mine engineering. Journal of Shanghai Jiaotong University (Science) 2015;20:21-5. https://doi.org/ 10.1007/s12204-015-1582-2.

[31] Collon P, Steckiewicz-Laurent W, Pellerin J, Laurent G, Caumon $\mathrm{G}$, et al. 3D geomodelling combining implicit surfaces and Voronoi-based remeshing: A case study in the Lorraine Coal Basin (France). Computers \& Geosciences. Elsevier 2015;77:29-43. 